\title{
Biological treatment of coal combustion wastes by Acidithiobacillus thiooxidans DSM 26636
}

\section{Tratamiento biológico de residuos de combustión de carbón por Acidithiobacillus thiooxidans DSM 26636}

Norma G. Rojas-Avelizapa*, Itzayana V. Hipólito-Juárez, Marlenne Gómez-Ramírez

Departamento de Biotecnología, Centro de Investigación en Ciencia Aplicada y Tecnología Avanzada del Instituto Politécnico Nacional, Querétaro, México.

*Corresponding author.

E-mail address: nrojasa@ipn.mx (N. G. Rojas-Avelizapa).

Article history:

Received: 16 December 2017 / Received in revised form: 25 April 2018 / Accepted: 4 May 2018 / Published online: 1 July 2018.

https://doi.org/10.29267/mxjb.2018.3.3.54

\begin{abstract}
The high levels of toxicity generated by the heavy metal content in industrial wastes has generated environmental and health concerns. One of the strategies to reduce the metallic load is the use of sulfur-oxidizing bacteria, due to its ability to produce sulfuric acid involved in the metal leaching. The aim of this research was to evaluate the growth of Acidithioobacillus thiooxidans DSM 26636 and its ability to leach metals from slags and ashes from coal combustion wastes. Microbial growth was monitoring by sulfate and sulfuric acid production. The metal content in slags and fly ashes was determined by ICPOES. The experiments were carried out during 21 days at $30^{\circ} \mathrm{C}, 150 \mathrm{rpm}$ in $125 \mathrm{~mL}$ Erlenmeyer flasks containing $30 \mathrm{~mL}$ of Starkey media added with $1 \%(\mathrm{w} / \mathrm{v})$ of elemental sulfur and $1 \%(\mathrm{w} / \mathrm{v})$ of slags or ashes. Results showed that Acidithioobacillus thiooxidans was able to leach V, Fe, Mg, Al, Si and Ni from slags. For fly ashes, metal leaching was Al, $\mathrm{Ni}, \mathrm{Sn}, \mathrm{Mg}, \mathrm{Zn}$ and Si. Summarizing, Acidithioobacillus thiooxidans could be used for the leaching of different metals contained in wastes from carbon combustion plant.
\end{abstract}


Keywords: Acithiobacillus thiooxidans, fly ashes, leaching, metals, slags, wastes

\section{RESUMEN}

Los altos niveles de toxicidad generados por el alto contenido de metales en los residuos industriales han generado problemas ambientales y de salud. Una de las estrategias para reducir la carga metálica en estos residuos podría ser mediante el uso de bacterias sulfooxidantes debido a que tienen la habilidad de oxidar azufre y producir ácido sulfúrico, el cual está implicado en la lixiviación de metales. Así, el objetivo de la presente investigación fue evaluar el crecimiento de Acidithioobacillus thiooxidans DSM26636 y su habilidad de lixiviar metales de escorias y cenizas de una planta de combustión de carbón. El crecimiento microbiano fue monitoreado mediante la producción de sulfatos y ácido sulfúrico. El contenido de metales en las escorias y cenizas se determinó mediante ICPOES. Los experimentos se llevaron a cabo durante 21 días a $30^{\circ} \mathrm{C}$ y $150 \mathrm{rpm}$ en matraces Erlenmeyer de $125 \mathrm{~mL}$ conteniendo $30 \mathrm{~mL}$ de medio Starkey modificado adicionado con azufre elemental al 1\%, las cenizas y/o escorias fueron adicionadas al 1\%. Los resultados mostraron que Acidithioobacillus thiooxidans fue capaz de lixiviar V, Fe, Mg, Al, Si y Ni de las escorias. En cuanto a las cenizas, los metales lixiviados fueron Al, Ni, Sn, Mg, Zn y Si. En resumen, Acidithioobacillus thiooxidans puede ser utilizada para la lixiviación de metales contenidos en residuos de escorias y cenizas provenientes de una planta de combustión de carbón.

Palabras clave: Acithiobacillus thiooxidans, cenizas, escorias, lixiviación, metales, residuos.

\section{INTRODUCTION}

The generation of combustion wastes is one of the lateral effects of energy production. Plants based on traditional fuels as coal, peat, fuel oil, gas are of particular concern. Percentages of $40-45 \%$ of all power generated worldwide derives from such sources (Nyashina et al., 2017; Karwowska et al., 2015). Although combustion wastes may be used in different applications such as components of industrial and building materials, their use is limited because of the significant content in heavy metals. However, combustion wastes also can be a source of valuable metals like $\mathrm{Fe}, \mathrm{Cu}, \mathrm{Cr}, \mathrm{Cd}, \mathrm{Al}, \mathrm{Pb}, \mathrm{Ni}, \mathrm{Zn}, \mathrm{Ag}$ and $\mathrm{Au}$ (Karwowska et al., 2015). Coal fly ash, a by-product of coal combustion in thermal power plants, is one of the most complex and abundant of anthropogenic materials. If not properly disposed of occurs, it can cause water and soil pollution, disrupt ecological cycles and pose environmental hazards. Metals sequestering from combustion ashes depends on the physical properties and composition of the ashes (Yao et al., 2014). Under favoring 
conditions, a considerable amount of these trace elements can easily be leached out from the surface of fly ash particles by the interaction with water in ponds or landfills. The water-soluble trace elements contaminate the soil, surface and ground water. It has been reported that the metal contaminants like $\mathrm{V}, \mathrm{Cr}, \mathrm{Ni}, \mathrm{Cd}$ and $\mathrm{Pb}$ are potential hazards to the environment even at low concentrations (Yao et al., 2015). The methods used for the treatment of wastes contaminated with metals are grouped in physical, chemical and biological. The innovative use of microorganisms for microscopic metal removal is considered more environmentally friendly than other means. A few microorganisms have demonstrated their ability in leaching metals (Chang et al., 2008). The microorganisms used in bioleaching processes include A. thiooxidans, A. ferrooxidans, A. caldus, Leptospirillum ferrooxidans, Sulfobacillus, Acidimicrobium and Ferroplasma species, as well as Sulfolobus, Acidianus and Metallosphaera. Acidithiobacillus thiooxidans is an extremely acidophilic bacterium, it is remarkably tolerant in acidic environment at $\mathrm{pH}$ of 1 or below. During bioleaching, bio-oxidation of elemental sulfur by A. thiooxidans produce $\mathrm{H}^{+}$that causes the decrease of $\mathrm{pH}$ that is involved in the bioleaching process (Zhou et al., 2014). The metabolites, mainly sulfuric acid, play a major role during bioleaching of heavy metals and is typically related to copper mining operations (bioleaching) (Chang et al., 2008; Yin et al., 2014). Acidithiobacillus group has been used for dissolution of $\mathrm{Cu}, \mathrm{Zn}, \mathrm{Fe}$ and As from different ores and wastes. Thus, nowadays metal recovery by biological means has emerged as an alternative technology. Based on previous data (Rojas-Avelizapa et al., 2013; Gomez-Ramírez et al., 2014a), the aim of this study was to evaluate the ability of $A$. thiooxidans to leach metals from coal combustion wastes such a slags and fly ashes.

\section{MATERIALS AND METHODS}

\subsection{Microorganism and culture media}

Sulfur-oxidizing bacteria used throughout this study was A. thiooxidans AZCT-M1256, this microorganism was deposited in Leibniz-Institut DSMZ - Deutsche Sammlung von Mikroorganismen und Zellkulturen GmbH (DSMZ) so now is called A. thiooxidans DSM 26636, which was isolated from a Mexican soil with high sulfur content (Rojas-Avelizapa et al., 2013). Culture medium used was a modified Starkey medium composed of (g/L): $\mathrm{KH}_{2} \mathrm{PO}_{4}, 3 ;\left(\mathrm{NH}_{4}\right)_{2} \mathrm{SO}_{4}, 0.2 ; \mathrm{MgSO}_{4} .7 \mathrm{H}_{2} \mathrm{O}, 0.5 ; \mathrm{CaCl}_{2} .2 \mathrm{H}_{2} \mathrm{O}, 0.3 ; \mathrm{FeSO}_{4} .7 \mathrm{H}_{2} \mathrm{O}, 0.1 ; 30 \mathrm{ppb}$ of molybdenum as $\mathrm{Na}_{2} \mathrm{MoO}_{4} \cdot 2 \mathrm{H}_{2} \mathrm{O}$; elemental sulfur was added at concentration of $1 \%$ (w/v). The medium was adjusted to $\mathrm{pH} 3$ with sulfuric acid (Takakawa et al., 1977).

\subsection{Coal combustion waste}

Slags and ashes came from a coal combustion plant located in Mexico. Metallic content was determined by ICP-OES following the methodology reported by Gómez-Ramirez et al in 2014b. The particle size was lower than $1000 \mu \mathrm{m}$. Slags and ashes were stored at room 
temperature until use.

\subsection{Growth of $A$. thiooxidans in presence of coal combustion wastes.}

The inoculum was prepared in $250-\mathrm{mL}$ flasks containing $50 \mathrm{~mL}$ of modified Starkey medium at $\mathrm{pH} 3$, elemental sulfur at $1 \%$, and incubated at $30^{\circ} \mathrm{C}, 150 \mathrm{rpm}$ during 3 days. Afterwards, inoculum was used to evaluate the ability of $A$. thiooxidans to grow in presence of slags and/or ashes wastes from a coke combustion plant at $1 \%(\mathrm{w} / \mathrm{v})$ pulp density added with elemental sulfur at $1 \%$. Experimental sets were prepared as follows: $125-\mathrm{mL}$ Erlenmeyer flasks containing $30 \mathrm{~mL}$ of modified Starkey medium were inoculated with 3 $\mathrm{mL}(10 \%)$ of the inoculum $\left(2 \times 10^{8} \mathrm{CFU} / \mathrm{mL}\right)$ and supplemented with the corresponding waste (slags or ashes). Flasks were incubated at $30^{\circ} \mathrm{C}, 150 \mathrm{rpm}$, during 21 days. Controls without inoculum were also included to determine abiotic sulfur-oxidizing activity. Every 7 days, flaks containing slags or ashes were sacrificed and the total content of flaks was collected in $50 \mathrm{~mL}$ Falcon tubes and centrifuged at $6000 \mathrm{rpm}$ during $7 \mathrm{~min}$; supernatant was filtrate and collected in $50 \mathrm{~mL}$ glass tubes with screw crap and stored at $4^{\circ} \mathrm{C}$ until use. Microbial growth was evaluated through sulfate determination according to the Mexican standard method (NMX-K-436-1977); each determination was performed in triplicate. The production of sulfuric acid in the supernatant was also evaluated by $\mathrm{pH}$ measurement using a digital potentiometer (ORION, Model 310) and by titration with sodium hydroxide solution $5 \mathrm{M}$ with bromothymol blue as acid-base indicator (Cerruti et al., 1998).

\subsection{Bioleaching activity}

Liquid samples $(1 \mathrm{~mL})$ corresponding to day 21 of biological treatment and abiotic control of each treatment were placed in cylindrical silicon carbide vials; $6 \mathrm{~mL}$ of concentrated $\mathrm{HNO}_{3}$ and $2 \mathrm{~mL}$ of concentrated $\mathrm{HCl}$ were added; samples were digested in a microwave reaction system (Multiwave PRO, Anton Paar) using an HF100 rotor. Digestion conditions were as follows: $600 \mathrm{~W}$ for six vessels, $40 \mathrm{bar}, 210-240^{\circ} \mathrm{C}$, with pRate of $0.3 \mathrm{bar} / \mathrm{sec}$, ramp $15 \mathrm{~min}$, hold $15 \mathrm{~min}$ and cooling at $55^{\circ} \mathrm{C}, 20 \mathrm{~mL}$ of deionized water was then added to the cylindrical vial, and the supernatant was collected and set to $50 \mathrm{~mL}$ using deionized water. Metals were analyzed at their respective wavelength (nm): Ag (328.068), Al (396.152), As (188.980), Ba (455.403), Be (313.042), Cd (214.439), Co (238.892), Cr (267.716), Cu (327.395), Fe (238.204), Li (670.783), Mg (279.553), Mn (257.610), Mo (202.032), Ni (231.604), Pb (220.353), Sb (206.834), Se (196.026), Si (251.611), Sn (189.925), Sr (407.771), Tl (190.794), V (292.401), Zn (213.857), Ti (336.122), W (207.912), Au (242.794), Ir (224.268), Os (225.585), Pd (340.458), Pt (214.424), Rh (343.488) and Ru (267.876). By using a inductively coupled plasma optical emission spectrometry analyses (ICP-OES, Varian Model 710-Es). The metals leached were calculated based on calibration curve of 0.25 to 6 ppm using commercial standards High Purity (Cat. \# ICP-200.7-6; Cat. \#ICP-MS-68A Solution B and Cat. \#ICP-MS-68A Solution C. Distilled water was used as blank, metal quantification data was processed by the software ICP expert II version 1.1. 
The effectiveness of biological treatment was determined by comparing the metal content in the slags or ashes at the beginning and at the end of biological treatment subtracting the abiotic metal loss in controls systems. Data were statistically analyzed using the Minitab 17 software with Tukey's HSD pairwise comparisons.

\section{RESULTS}

As can be observed in Table 1, ICP-EOS analyses showed that slags and ashes wastes from a coal combustion plant contain mainly $\mathrm{V}, \mathrm{Fe}, \mathrm{Ni}, \mathrm{Al}, \mathrm{Mg}, \mathrm{Si}, \mathrm{Ti}, \mathrm{Ba}, \mathrm{Cr}$ and $\mathrm{Zn}$, another metals were also detected with values below $500 \mathrm{mg} / \mathrm{Kg}$.

Table 1. Metal composition of slags and ashes quantified by ICP-EOS

\begin{tabular}{c|r|r|r|r|r}
\hline Metals & \multicolumn{1}{c|}{$\begin{array}{c}\text { Slags } \\
(\mathbf{m g} / \mathbf{k g})\end{array}$} & $\begin{array}{c}\text { Ashes } \\
(\mathbf{m g} / \mathbf{k g})\end{array}$ & Metals & $\begin{array}{c}\text { Slags } \\
(\mathbf{m g} / \mathbf{k g})\end{array}$ & \multicolumn{1}{c}{$\begin{array}{c}\text { Ashes } \\
(\mathbf{m g} / \mathbf{k g})\end{array}$} \\
\hline \hline $\mathbf{V}$ & 126042,8 & 86325,8 & $\mathbf{T l}$ & 325,1 & 260,7 \\
$\mathbf{F e}$ & 42057,1 & 36534,9 & $\mathbf{M n}$ & 278,3 & 459,9 \\
$\mathbf{N i}$ & 38721,5 & 35693,1 & $\mathbf{M o}$ & 112,7 & 1091,0 \\
$\mathbf{A l}$ & 31100,2 & 14209,6 & $\mathbf{O s}$ & 107,8 & 143,7 \\
$\mathbf{M g}$ & 19759,5 & 20892,7 & $\mathbf{I r}$ & 94,1 & 87,9 \\
$\mathbf{S i}$ & 4220,6 & 4535,7 & $\mathbf{P d}$ & 76,7 & 62,1 \\
$\mathbf{T i}$ & 1606,4 & 452,0 & $\mathbf{W}$ & 73,8 & 67,6 \\
$\mathbf{B a}$ & 1512,4 & 887,4 & $\mathbf{C o}$ & 71,6 & 7,8 \\
$\mathbf{C r}$ & 1072,8 & 387,0 & $\mathbf{C u}$ & 56,5 & 123 \\
$\mathbf{Z n}$ & 1012,4 & 873,8 & $\mathbf{P t}$ & 18,6 & 19,0 \\
$\mathbf{R u}$ & 950,8 & 475,6 & $\mathbf{S b}$ & 4,7 & 0,0 \\
$\mathbf{A s}$ & 431,1 & 377,4 & $\mathbf{P b}$ & 0,0 & 33,1 \\
$\mathbf{S n}$ & 377,2 & 355,2 & & & \\
\hline \hline
\end{tabular}

\subsection{Growth ability of $\boldsymbol{A}$. thiooxidans in presence of coal combustion wastes}

The ability of growth of $A$. thiooxidans in presence of slags and ashes wastes at $1 \%(\mathrm{w} / \mathrm{v})$ pulp density was evaluated by means of sulfate and sulfuric acid production as mentioned previously. Figure 1 shows the ability of $A$. thiooxidans to oxidize elemental sulfur in presence of slags and ashes wastes. Higher sulfate concentrations detected during growth of A. thiooxidans in presence of ashes wastes corresponded to $28,544 \mathrm{mg} / \mathrm{L}$ at day 14 corresponding with $95 \%$ of sulfur oxidized, later a less sulfate concentrations was detected at day 21 with value of $18,600 \mathrm{mg} / \mathrm{L}$, while in slags it was lower than $1700 \mathrm{mg} / \mathrm{L}$ and not significant changes were detected during all treatment and corresponding with $5.6 \%$ of sulfur oxidized. 


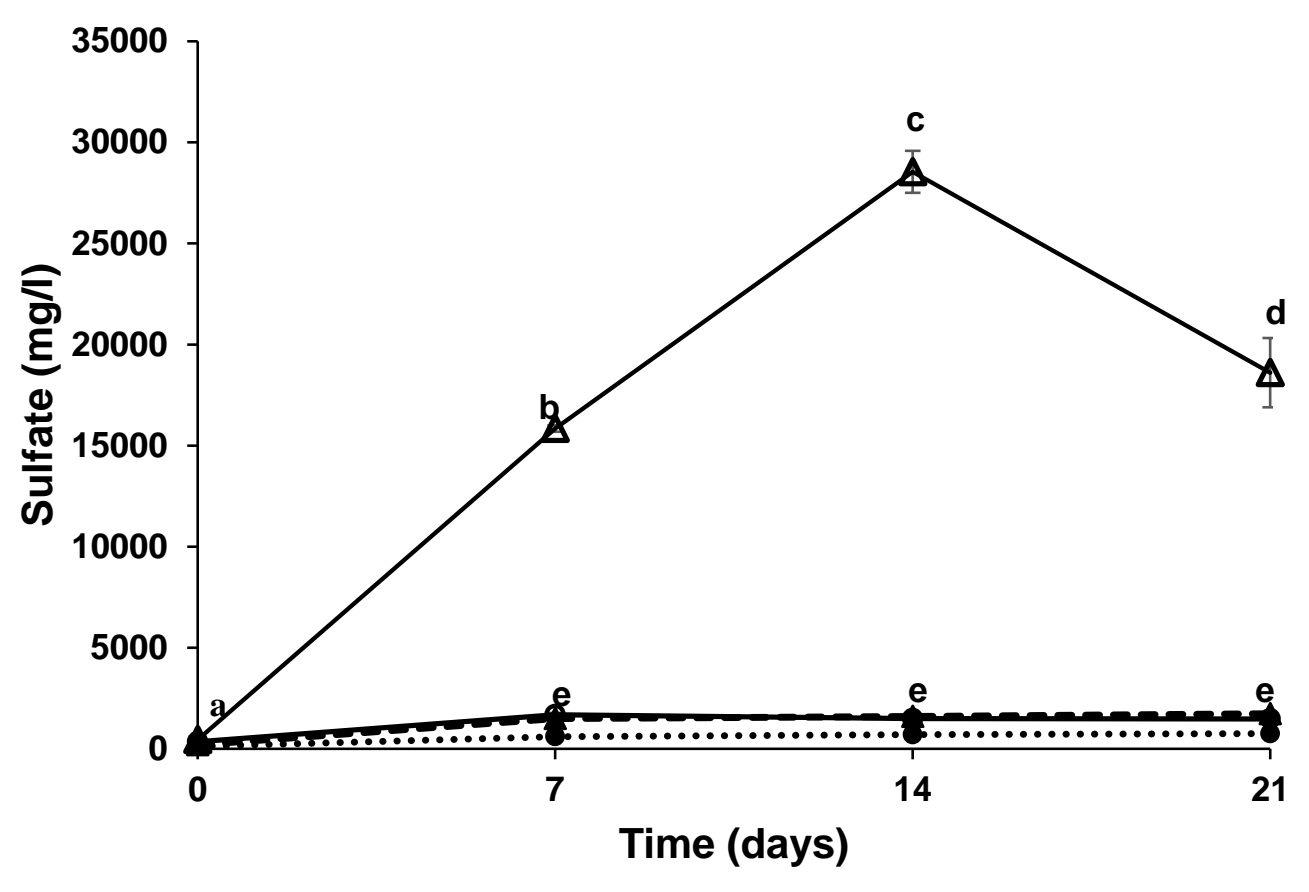

Fig. 1. Monitoring of sulfate detected during microbial treatment of slags and ashes coal combustion wastes at $1 \%$ by $A$. thiooxidans at $30^{\circ} \mathrm{C}, 150 \mathrm{rpm}$. Controls and experimental are indicated as control slags ..-..; slags $\boldsymbol{-} \boldsymbol{-}$; control ashes $\mathbf{-} \boldsymbol{\Delta}$; ashes $\boldsymbol{\Delta}$. Statistically significant differences (one-way ANOVA with Tukey's HSD $(\mathrm{P}<0.05)$ are indicated by different letters.

The sulfuric acid is produced when elemental sulfur and reduced inorganic sulfur compounds (RICSs) are oxidized by sulfur-oxidizing microorganisms such as $A$. thiooxidans. In presence of slags, a concentration of $0.04 \mathrm{M}$ of sulfuric acid was detected during all treatment in comparison when $0.20 \mathrm{M}$ of sulfuric acid was detected in presence of ashes. Higher concentrations of sulfuric acid $(0.18-0.20)$ occurred in presence of ashes (Figure 2). 


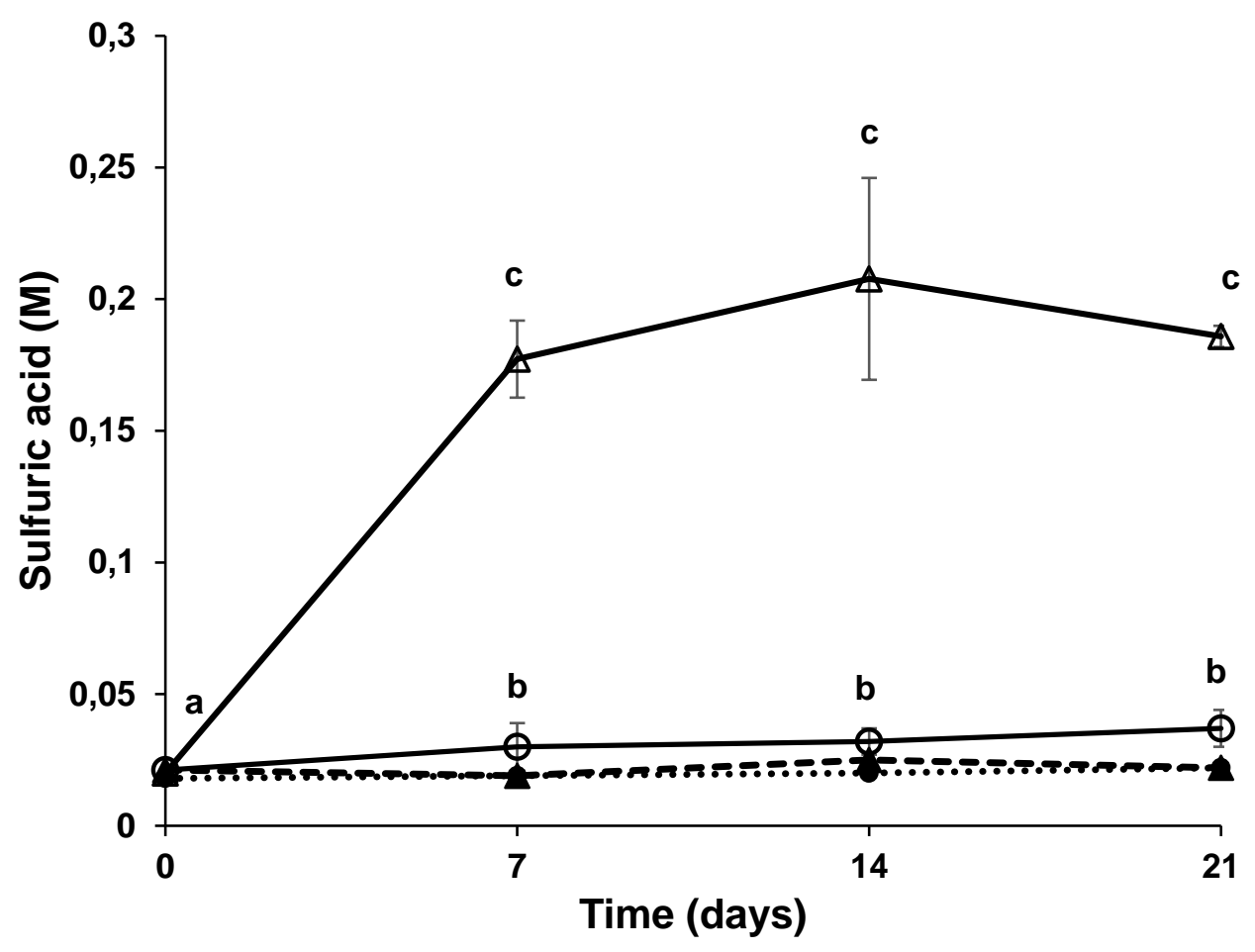

Fig. 2. Monitoring of sulfuric acid detected during the microbial treatment of slags and ashes by A. thiooxidans at $30^{\circ} \mathrm{C}, 150 \mathrm{rpm}$. Controls and experimental are indicated as

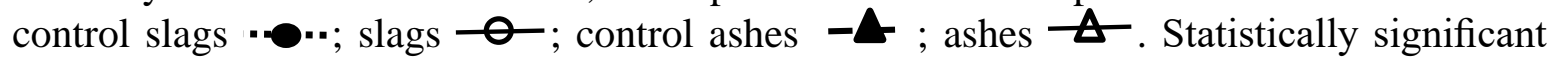
differences (one-way ANOVA with Tukey's HSD (P < 0.05) are indicated by different letters.

Figure 3 shows the $\mathrm{pH}$ reduction in all systems in comparison with abiotic control. In presence of slags, the control system showed a slight increase of 3 to 3.3 units in comparison with biological treatment the $\mathrm{pH}$ decreased from 2.8 to 2.3 units while for ashes treatments control system showed a pH decrease from 2.9 to 2.3 units and 2.8 to 0.68 units to biological treatment. Slags combustion wastes affected the sulfur oxidizing activity of $A$. thiooxidans because in presence of this waste, a lower $\mathrm{pH}$ reduction was observed, while $\mathrm{pH}$ decrease in presence of ashes was more significant, however in both wastes the microorganism has the ability to oxidize sulfur but at different extent. 


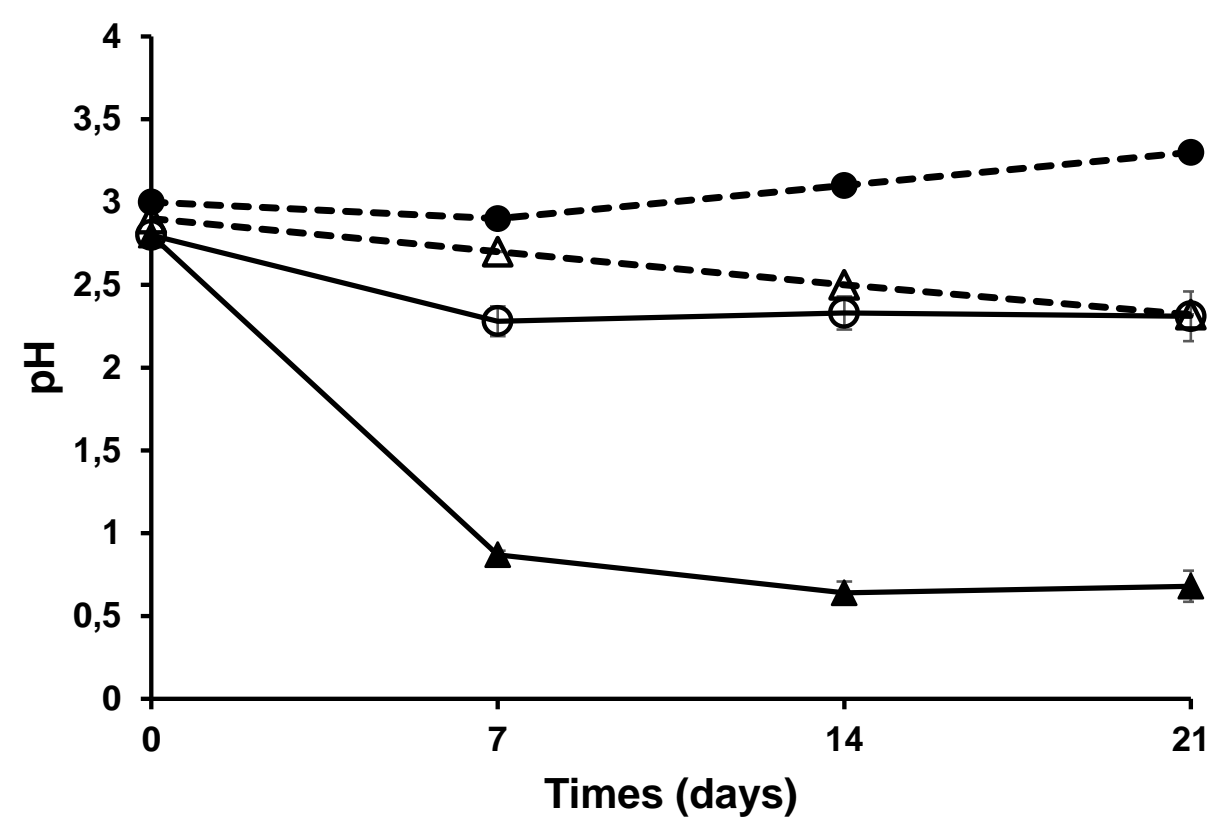

Fig. 3. Monitoring of $\mathrm{pH}$ during the microbial treatment of slags and ashes by $A$. thiooxidans $1 \%, 30^{\circ} \mathrm{C}, 150 \mathrm{rpm}$. Controls and experimental are indicated as control slags -•..; slags $-\boldsymbol{O}$; control ashes $\boldsymbol{-} \boldsymbol{\Delta}$; ashes $\boldsymbol{\Delta}$.

\subsection{Metal removal from slags and ashes}

According with results, sulfuric acid produced by A. thiooxidans during sulfur oxidation was able to leach metals from slags and ashes. The metals bioleached were evaluated by ICP-OES at the end of biological treatment. Figure 4 shows, the concentration of metals that were leached in liquid media, as can be observed in slags the metal that were primarily leached in $\mathrm{mg} / \mathrm{Kg}$ were $\mathrm{V}(48) ; \mathrm{Fe}(29) ; \mathrm{Mg}$ (25); $\mathrm{Al}(15) ; \mathrm{Si}(10)$ and $\mathrm{Ni}$ (7.4) corresponding to removal percentages of $0,04 \%, 0,07 \%, 0,13 \%, 0,05 \%, 0,24 \%$ and 0,02 $\%$ respectively while for ashes more metals concentrations were detected in liquid media corresponding in $\mathrm{mg} / \mathrm{Kg}$ to $\mathrm{Al}$ (249); $\mathrm{Ni}$ (90); $\mathrm{Sn}$ (40); $\mathrm{Mg}$ (40); $\mathrm{Zn} \mathrm{(30)} \mathrm{and} \mathrm{Si}$ (30) corresponding to removal percentages of $1,76 \%, 0,25 \%, 11,26 \%, 0,19 \%, 3,46 \%$ and $0,66 \%$ respectively. The highest efficiency in bioleaching was observed for ashes. It was observed than the $\mathrm{pH}$ of biological treatment was lower in media containing ashes than in slags as it was mentioned previously. Differences in the ability of A. thiooxidans to leach metals can be affected by the properties of the raw material. Results showed that ashes were more easily bioleached than slags. 


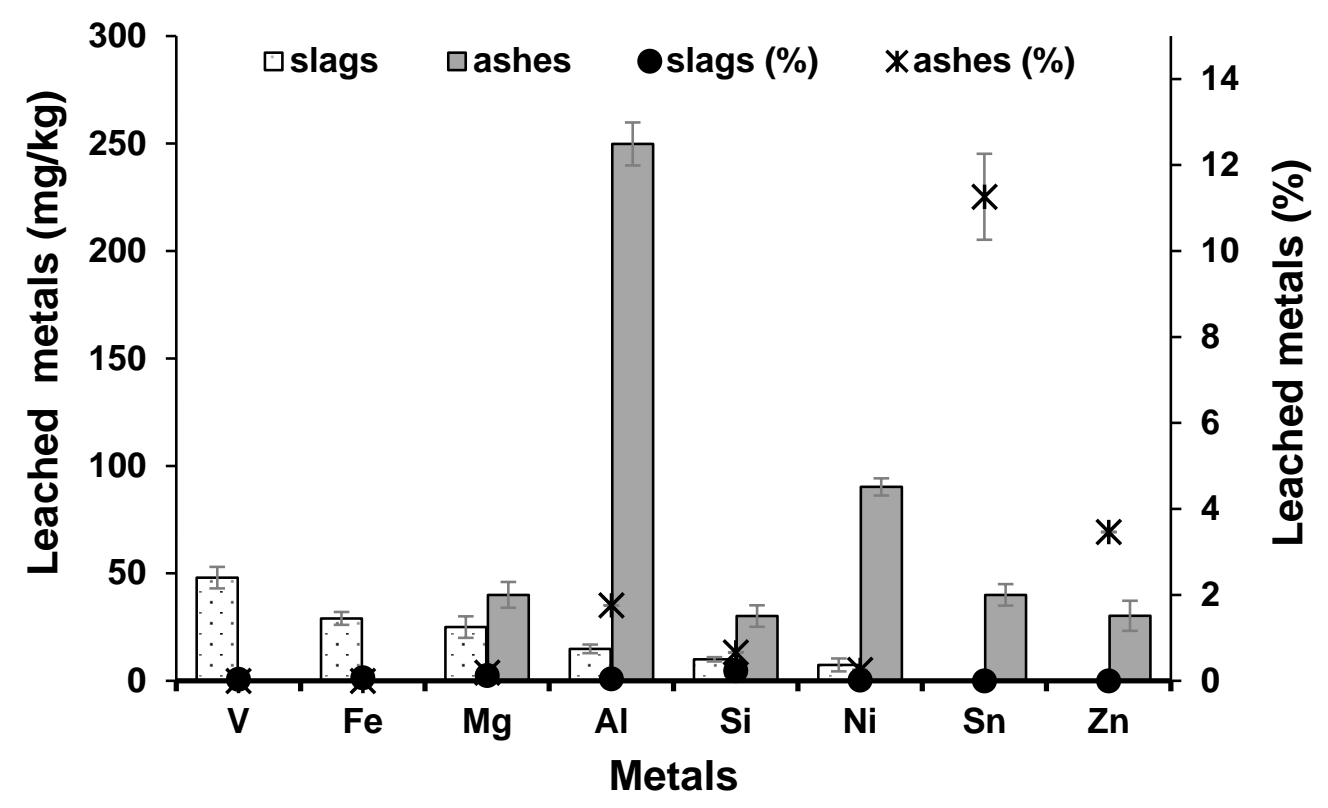

Fig. 4. Bioleached metals in $(\mathrm{mg} / \mathrm{Kg})$ and removal percentages from slags and ashes wastes at $1 \%(\mathrm{w} / \mathrm{v})$ pulp density at $1 \%$ by A. thiooxidans after 21 days of treatment, $30^{\circ} \mathrm{C}$, $150 \mathrm{rpm}$.

\section{DISCUSSION}

Previous studies showed that $A$. thiooxidans used in this study has the ability to grow autotrophycally using elemental sulfur at concentrations within 1 to $9 \%(\mathrm{w} / \mathrm{v})$ as energy source in a pH range of 3 to 7 (Rojas-Avelizapa et al., 2013) with a sulfur removal rate of $0.185 \mathrm{mg} \mathrm{S} \mathrm{g}^{-1} \mathrm{~h}^{-1}$ with a $16.5 \%$ (w/v) of solid industrial waste provided by the Mexican Petroleum Institute (IMP) (Gómez-Ramírez et al., 2014b). During sulfur oxidation an initial contact on the hydrophobic surface is required, this is an essential step in sulfur oxidation process so there is the possibility that bacteria modify their ability to fix the sulfur particles due to the production of phospholipids that contribute to the dissolution of sulfur, changing its hydrophobic character (Pich-Otero et al., 1995), altering the wettability of elemental sulfur increasing the adsorption of sulfur-oxidizing bacteria on the hydrophobic surface of sulfur which facilitate that microorganisms fix and more rapidly oxidize sulfur particles contained in the solid waste. Reports have mentioned that $A$. caldus can produce $\mathrm{H}_{2} \mathrm{SO}_{4}$ using elemental sulfur reaching an averaged cumulative concentration of $0.45 \mathrm{M}$ over a period of 16 days, A. thioxidans using elemental sulfur reaches $0.224 \mathrm{~g}$ DCW/L with $0.15 \mathrm{M}$ of $\mathrm{H}_{2} \mathrm{SO}_{4}$ in 8 to 11 days (Basitere et al., 2012). In our study, the highest sulfate and sulfuric acid concentration detected by A. thiooxidans were 28,544 $\mathrm{mg} / \mathrm{L}$ and $0.18 \mathrm{M}$ respectively over a period of 14 days in presence of ashes in comparison with $1,700 \mathrm{mg} / \mathrm{L}$ and $0.032 \mathrm{M}$ of sulfate and sulfuric acid production detected in presence 
of slags. The $\mathrm{H}_{2} \mathrm{SO}_{4}$ productivity clearly depends on the type of waste used, the sulfur surface area, the population of cells, the uniform contact between the liquid-solid-gas (Cerruti et al., 1998). The highest sulfur oxidizing activity was detected in ashes which could be attributed to less metallic load of some elements potentially toxic for bacteria for example $\mathrm{Cr}$ at $387 \mathrm{mg} / \mathrm{Kg}$ in ashes comparing with $1072,8 \mathrm{mg} / \mathrm{Kg}$ in slags. $\mathrm{Cd}(\mathrm{II})$ is toxic to microorganisms through a variety of mechanisms, including binding to thiol groups, protein denaturation and interaction with calcium and zinc metabolism. However, $\mathrm{Cd}(\mathrm{II})$ toxicity is greater than that of zinc and copper to A. ferrooxidans (Dopson et al., 2003). Nickel at a concentration of $35,639 \mathrm{mg} / \mathrm{Kg}$ and $38,721 \mathrm{mg} / \mathrm{Kg}$ in ashes and slags respectively. Sulfur and sulfite oxidation and $\mathrm{CO}_{2}$ incorporation were strongly inhibited by $5 \mathrm{mM} \mathrm{Ni(II)}$ in A. thiooxidans. it was shown that Ni(II) binds to the cell surface, where it inhibits the RISC enzymes sulfur dioxygenase and sulfite oxidase, and ultimately growth (Dopson et al., 2003). Regarding to $\mathrm{pH}$ changes, carbonates contained in slags could influence to maintain the $\mathrm{pH}$ of the system, so the sulfur oxidizing activity was not promoted, because the efficiency of acidophilic bacteria in releasing metals from some alkaline wastes, including ashes and slags, may be limited (Karwowska et al., 2015). In slags and ashes, the $\mathrm{pH}$ reduction respect to control system, in slags the $\mathrm{pH}$ reduction could be attributed to low production of sulfuric acid and its was not enough to neutralize the action provided by the silicates as it is mentioned by Potysz et al, (2016), in ashes the $\mathrm{pH}$ reduction was observed, the continued decrease of $\mathrm{pH}$ solution may either be due to: i) microbial $\mathrm{S}$ oxidation and consequent formation of sulfuric acid or ii) the dissolution of sulfides. It is noteworthy to mention that sulfide dissolution also includes intermediate sulfur species, including polysulfide and elemental sulfur, which serves as a source for the microbial production of sulfuric acid (Potysz et al., 2016). Bioleaching of heavy metals by sulfuric acid it's considered a complex process. Various parameters such as temperature, $\mathrm{pH}$, bacteria, sulfur content, cell concentration, surface area of metals, particle size, pulp density, speed of rotation and sulfur content. etc., play important roles in determining the metal leaching rate (Chang et al., 2008; Gholami et al., 2011). Increasing the metals concentration requires increasing the tolerance of the bacteria, as heavy metals are able to exert harmful effects due to their strong coordinating capabilities. These toxic effects include blocking of biologically important functional groups and the denaturation of enzymes (Gholami et al., 2011). Travisany et al (2014), report the genome sequence of $A$. thiooxidans Licanantay, the first strain from a copper mine and was compared with two other A. thiooxidans non-metal mining strains, they determined that these strains share a large core genome of 2109 coding sequences and a high average nucleotide identity over 98\%. Nevertheless, the presence of 841 strain-specific genes (absent in other A. thiooxidans strains) suggests a particular adaptation of Licanantay to its specific bio-mining environment. Their highlight genes encoding for proteins involved in heavy metal tolerance, mineral cell attachment and cysteine biosynthesis. Several of these genes were located near genetic motility genes in genomic regions of over $10 \mathrm{kbp}$ absent in the other strains. Hee-Chang et al (2017) reported that they overcoming bacteriostatic effects of 
heavy metals on A. thiooxidans for direct bioleaching of saprolitic Ni laterite ores; heavy metal tolerance was achieved by the bacterium during the leaching process, results confirm the robust nature and suitability of $A$. thiooxidans in direct bioleaching of $\mathrm{Ni}$ ores. In our study A. thiooxidans was able to leach metals as $\mathrm{V}, \mathrm{Fe}, \mathrm{Mg}, \mathrm{Al}, \mathrm{Si}$ and $\mathrm{Ni}$ from slags and $\mathrm{Al}, \mathrm{Ni}, \mathrm{Sn}, \mathrm{Mg}, \mathrm{Zn}$ and $\mathrm{Si}$ from ashes at the end of 21 days, during this period most probably A. thiooxidans was adapted and acclimatized to heavy metal concentrations and it has been attributed to the activation of alternative biochemical pathways which allow cells to continue growing, some of the mechanisms involved to tolerance could be similar to mentioned above, however to known the mechanism involved in A. thiooxidans used in this study it would be necessary to evaluate genes and enzymes expression in presence of slags and ashes. Regarding to coal combustion wastes, the chemical composition of slags and ashes strongly depends on the type of material that it is burned and the incineration technology (Karwowska et al., 2017). Table 1 shows metal composition of slags and ashes, metals as V, Fe, Ni, Al, Mg, Si, Ti, Ba, Cr, and $\mathrm{Zn}$ are above $1000 \mathrm{mg} / \mathrm{Kg}$ in slags and metals $\mathrm{V}, \mathrm{Fe}, \mathrm{Ni}, \mathrm{Al}, \mathrm{Mg}$ and $\mathrm{Si}$ are above $1000 \mathrm{mg} / \mathrm{Kg}$ in ashes. The rest of metals are below $1000 \mathrm{mg} / \mathrm{Kg}$ in both wastes. Karwowsk et al (2015) evaluated the influence of metal speciation in combustion waste on the efficiency of $\mathrm{Cu}, \mathrm{Pb}, \mathrm{Zn}, \mathrm{Cd}, \mathrm{Ni}$ and $\mathrm{Cr}$ bioleaching by a mixed culture of sulfur-oxidizing and biosurfactant-producing bacteria, they concluded that metal speciation is an important factor that influences the efficiency of metal bioleaching from combustion wastes. The best bioleaching results were obtained for power plant slag, which had a high metal content in the exchangeable, bound to carbonates and bound to $\mathrm{Fe}$ and $\mathrm{Mg}$ oxides fractions, the metal recovery percentage for $\mathrm{Zn}, \mathrm{Cu}$ and $\mathrm{Ni}$ from this waste exceeded 90\%. In our research, metal percentage leached was lower if it is compared with previous one which could be attributed to physic-chemical properties of waste besides not being separated in fractions (exchangeable fractions, fractions bound to carbonates, fractions bound to iron and manganese oxides and fractions bound to organic matter), including their speciation, fraction bound to carbonates and fraction bound to organic matter and metal bioleaching from larger particles usually needs the dissolution of the matrix of the leached material. Karwowska et al., (2015) mention that the combustion waste from the waste incineration plant was the least susceptible to biological leaching. The metals recovery percentage did not exceed $20 \%$. The speciation analysis revealed the predomination of residual fraction and the lower leachability could be also related to the large size of the waste particles (1-10 mm). Chou et al 2009, mentioned that the lowered bioleaching efficiency of metals present in the fraction bound to organic matter. To release metals from the organic fraction, the organic matter needs to be degraded under oxidizing conditions. So the lower sulfur oxidizing activity and metals bioleaching in slags waste could be attributed, in addition to the high metal content, to the presence of organic matter bbeing able to inhibit the growth of $A$. thiooxidans. Higher pulp density (higher solid content of $3 \%)$ and particle size $(<0.3 \mathrm{~mm})$ could be involved in both the neutralizing potential and had an effect on the bioleaching efficiency. These parameters could inhibit the bioleaching performance or at least extended the time required by $A$. thiooxidans for 
sulfuric acid production (Potysz et al., 2016). The biologically produced $\mathrm{H}_{2} \mathrm{SO}_{4}$ by $A$. thiooxidans showed a potential to reduce the metal content in slags and ashes, however the process needs to be optimized to reduce considerably the metal content in combustion wastes.

\section{ACKNOWLEDGEMENTS}

This research received financial support by Secretary of Science, Technology and Innovation of Mexico City, Project SECITI/063/2016 and the National Polytechnic Institute.

\section{CONFLICT OF INTEREST}

All the researchers listed as authors of the current study declare that there is no conflict of interests regarding the publication of this manuscript.

\section{REFERENCES}

Basitere M., Ntwampe S. K. O., Sheldon M. S. 2012. Optimal sulphuric acid production using Acidithiobacillus caldus (DSM 8584): Bioprocess design for application in ionexchange. African Journal of Biotechnology. 11(83): 14946-14955.

Cerruti C., Curutchet G., Donati E. 1998. Bio-dissolution of spent nickel-cadmium batteries using Thiobacillus ferrooxidans. Journal of Biotechnology. 62: 209-219

Chang J.H., Hocheng H., Chang H.Y., Shih A. 2008. Metal removal rate of Thiobacillus thiooxidans without pre-secreted metabolite. Journal of Materials Processing Technology. 201: 560-564.

Chou J.D., Wey M.J., Chang S.H. 2009. Evaluation of the distribution patterns of $\mathrm{Pb}, \mathrm{Cu}$ and Cd from MSWI fly ash during thermal treatment by sequential extraction procedure. Journal of Hazardous Materials. 162:1000-006.

Dopson M., Baker-Austin C., Koppineedi P.R., Bond P.L. 2003. Growth in sulfidic mineral environments: metal resistance mechanisms in acidophilic micro-organisms. Microbiology. 149:1959-1970.

Gholami R.M., Borghei S.M., Mousavi S.M. 2011. Bacterial leaching of a spent Mo-CoNi refinery catalyst using Acidithiobacillus ferrooxidans and Acidithiobacillus thiooxidans. Hydrometallurgy. 106: 26-31

Gomez-Ramirez M., Zarco-Tovar k., Aburto j., García de León r., Rojas-Avelizapa N.G. 2014a. Microbial treatment of sulfur-contaminated industrial waste. Journal of Environmental Science and Health part A. 49(2):228-232. 
Gómez-Ramírez M., Flores-Martínez Y.A., López-Hernández L.J., Rojas-Avelizapa N.G. 2014b. Effect of $\mathrm{Fe}^{2+}$ Concentration on Microbial Removal of $\mathrm{Ni}$ and $\mathrm{V}$ from Spent Catalyst. Journal of Chemical, Biological and Physical Sciences. Special Issue, Section B, 4(5):101-109.

Hee-Chan J \& Valix M. 2017. Overcoming the bacteriostatic effects of heavy metals on Acidithiobacillus thiooxidans for direct bioleaching of saprolitic $\mathrm{Ni}$ laterite ores. Hydrometallurgy. 168: 21-25.

Karwowska E., Wojtkowska M., Andrzejewska D. 2015. The influence of metal speciation in combustion waste on theefficiency of $\mathrm{Cu}, \mathrm{Pb}, \mathrm{Zn}, \mathrm{Cd}, \mathrm{Ni}$ and $\mathrm{Cr}$ bioleaching in a mixed culture ofsulfur-oxidizing and biosurfactant-producing bacteria. Journal of Hazardous Materials. 299: 35-41.

Maluckov B.S. 2017. The Catalytic Role of Acidithiobacillus ferrooxidans for Metals Extraction from Mining - Metallurgical Resource. Biodiversity International Journal. 1(3): 00017

NMX-K-436-1977. 1977. Determinación del ión sulfato en muestras de aguas para alimentación de calderas. Secretaria de Comercio y Fomento Industrial

Nyashina G. S., Shlegel N. E., Strizhak P. A. 2017. Emissions in the Combustion of Coal and Coal-Processing Wastes. Coke and Chemistry. 60(4): 171-176.

Potysz A., Lens P.N.L., Vossenberg J.V.D., Rene E.R., Grybos M., Guibaud G., Kierczak J., Hullebusch E.D.V. 2016. Comparison of $\mathrm{Cu}, \mathrm{Zn}$ and $\mathrm{Fe}$ bioleaching from $\mathrm{Cu}-$ metallurgical slags in the presence of Pseudomonas fluorescens and Acidithiobacillus thiooxidans. Applied Geochemistry. 68:39-52.

Rojas-Avelizapa N. G., Gómez-Ramírez, M., Hernández-Gama, R., Aburto, J. and García de León, R. 2013. Isolation and selection of sulfur-oxidizing bacteria for the treatment of sulfur-containing hazardous wastes. Chemical And Biochemical Engineering Quarterly. 27(1): 109-117.

Takakuwa S., Nishiwaki T., Hosoda K., Tominaga N., Iwasaki H. 1977. Promoting effect of molybdate on the growth of a sulfur-oxidizing bacterium, Thiobagillus thiooxidans. The Journal of General and Applied Microbiology. 23: 163-173.

Travisany D., Cortés M.P., Latorre M., Genova A.D., Budinich M., Bobadilla-Fazzini R.A., Parada P., González M., Maass A. 2014. A new genome of Acidithiobacillus thiooxidans provides insights into adaptation to a bioleaching environment. Research in Microbiology. 165(9): 743-752.

Yao Z.T., Xia M.S., Sarker P.K., Chen T. 2014. A review of the alumina recovery from coal fly ash, with a focus in China. Fuel. 120: 74-85. 
Yao Z.T., Ji X.S., Sarker P.K., Tang J.H., Ge L.Q., Xia M.S., Xi Y.Q. 2015. A comprehensive review on the applications of coal fly ash. Earth-Science Reviews. 141: $105-121$

Yin H., Zhang, X., Li X., He Z., Liang Y., Guo X., Hu Q., Xiao Y., Cong J., Ma L., Niu J., Liu X. 2014. Whole-genome sequencing reveals novel insights into sulfur oxidation in the extremophile Acidithiobacillus thiooxidans. BMC Microbiology.14:179.

Zhou J., Zheng G., Zhang X., Zhou L. 2014. Influences of Extracellular Polymeric Substances on the Dewaterability of Sewage Sludge during Bioleaching. PLOS ONE. 9(7): $1-9$. 